\title{
Household Allocation of Time and Church Attendance
}

\section{Corry Azzi}

\author{
Lawrence University
}

\section{Ronald Ehrenberg}

University of Massachusetts, Amherst

\begin{abstract}
This paper presents the first systematic attempt by economists to analyze the determinants of individuals' participation in religious activities. A multiperiod utility-maximizing model of household behavior is developed which includes among its implications the shape of a household's life-cycle religious-participation profile and the division of religious participation between husband and wife. The theory is empirically tested using statewide church-membership data and survey data on individuals' frequency of church attendance. The paper concludes by discussing several extensions of the model which lead to additional potentially testable hypotheses.
\end{abstract}

This paper presents the first systematic attempt by economists to analyze the determinants of "religiosity," individuals' religious commitment, and participation in church-related activities. Previous research on the subject conducted by sociologists and psychologists has concentrated on the empirical correlates of religiosity. These studies, using primarily simple correlations or two-way tabular comparisons, have indicated that variables such as race, sex, income, social class, and education tend to be associated

Our names are listed in alphabetical order. We are grateful to the numerous individuals who have given us comments on earlier versions of the paper, including Gary Becker, Daniel Hamermesh, Walter Oi, Sherwin Rosen, Theodore W. Schultz, George Stigler, and two referees. None of these individuals is responsible, however, for any errors that remain. An earlier version of the paper was presented to a "Workshop on Applications of Economic Theory" at the University of Chicago, and our concluding section is largely a product of that workshop.

[Journal of Political Economy, 1975, vol. 83, no. 1] (C) 1975 by The University of Chicago. All rights reserved. 
with various dimensions of religiosity. ${ }^{1}$ However, a systematic theory of religious participation which simultaneously explains all (or most) of these associations has yet to be developed. ${ }^{2}$

A rapidly growing number of papers by economists has analyzed the allocation of household members' time among various market and nonmarket activities. ${ }^{3}$ Recent papers include analyses of the determinants of family size (fertility), household formation (marriage), the value of housewives' time, household nonmarket production, household investments in health, and even suicide rates. ${ }^{4}$ Since household members' participation in religious activities requires the use of their time, it seems logical for economists to utilize a similar framework to analyze certain dimensions of religiosity. We utilize such a framework in this paper as the basis for an empirical investigation of variations in church membership and church-attendance rates. Moreover, as we indicate in the concluding section, our framework can be easily extended in several directions to allow one to analyze a wider range of phenomena relating to the interaction of household allocation of time and religiosity.

There is one crucial element, however, that distinguishes an analysis of religious participation from an analysis of participation in other activities. All previous household-allocation-of-time models assume that the expected stream of "benefits" which an individual plans to receive terminates at the time of his death. This assumption is inappropriate for a model of religious participation because most religions promise their members some form of an afterlife. Furthermore, the expected afterlife benefits are often viewed by individuals as being at least partially related to their lifetime allocation of time to religious activities. This suggests that household participation in church-related activities should be analyzed in the context of a multiperiod household-allocation-of-time model which allows for "afterlife consumption," with this variable being at least partially a function of the household's investment of members' time in religious activities during their lifetimes.

In this paper we first provide some evidence on variations in churchattendance rates over time and across individuals and in church-membership rates over areas as well as indicate briefly the empirical correlates of religiosity uncovered by sociologists and psychologists. Next, we outline a multiperiod utility-maximizing model of household behavior which suggests the determinants of household religious participation, including the division of participation between husband and wife and a household's

${ }^{1}$ Examples of this literature are Bultena (1948), Lenski (1953, 1962), Argyle (1959), Lazarwitz (1961), Orbach (1961), Demerath (1965), Glock and Stark (1965), Roof (1972), Sales (1972), and Sklare (1972).

${ }^{2}$ As Roof (1973) indicates, sociologists are well aware of this point.

3 These papers are based upon the pioneering work of Becker (1965).

${ }^{4}$ See, respectively, Willis (1973), Becker (1973), Gronau (1973), Michael (1973), Grossman (1972), and Hamermesh and Soss (1974). 
life-cycle religious-participation profile. While the model is based to a large extent on the salvation motive for religious participation, other motives are introduced, and we indicate how they alter the implications of the model. In the third section, we empirically test our theory using multivariate methods and two different types of data: statewide data on church-membership rates for 1952, 1936, and 1926; and survey data on the frequency of church attendance for 1,500 U.S. adults in 1973. Finally, we suggest several extensions of the model which lead to numerous other potentially testable hypotheses.

\section{Background Data and Prior Research}

Sociologists have emphasized the multidimensional nature of religiosity, including church membership, church attendance, religious devotionalism, and the extent of orthodox belief. Moreover, empirical studies have indicated that the correlations of the various dimensions with any given socioeconomic variable are not likely to be identical. For example, church attendance has generally been found to be positively associated with measures of social class, while religious devotionalism has been found to be negatively associated. Our research abstracts from the multidimensional nature of religiosity and focuses on church membership and the frequency of church attendance. More generally we are concerned with the household's allocation of time toward religious activities, and we take its members' religious beliefs as predetermined. That is, we attempt to explain the allocation of time to religious activities given religious belief rather than religious belief itself.

Table 1 presents background information on church attendance in the United States. Section A, based on Gallop Poll results, indicates that over the last 30 years church attendance in a given week has fluctuated between 36 and 49 percent of the population, with the fraction of the population attending church in any given week declining steadily since 1958. ${ }^{5}$ Unfortunately, the small number of time-series observations makes it impossible to meaningfully test any model of the determinants of church-attendance rates with this national data. Section B indicates, however, that the frequency of church attendance also varies substantially across individuals. We use the cross-section survey data upon which this table is based to test our model in Section III below. Table 2 presents church-membership rates by state for 1926, 1936, and 1952, the last three years in which church-membership figures by state were collected by either a public or private organization. Church-membership statistics are notoriously poor in quality. The number of denominations reporting

\footnotetext{
${ }^{5}$ Argyle (1959) has presented similar data for the 1900-1937 period in Great Britain. He cautions that individuals tend to overstate their frequency of church attendance.
} 
TABLE 1

A. Percentage of Americans Who Attend Church Each Week, Selected YeARs 1939-73

\begin{tabular}{|c|c|c|c|c|c|}
\hline Year & $\%$ & Year & $\%$ & Year & $\%$ \\
\hline 1939. & 41 & 1957. & 47 & 1965. & \\
\hline 1940. & 37 & 1958. & 49 & 1966. & \\
\hline 1942. & 36 & 1959. & 47 & 1967. & 5 \\
\hline 1947. & 45 & 1960. & 47 & 1968. & \\
\hline 1950. & 39 & 1961 . & 47 & 1969. & 2 \\
\hline 1954. & 47 & 1962. & 46 & 1970. & \\
\hline 1955. & 49 & 1963. & 46 & 1971. & \\
\hline 1956. & 46 & 1964. & 45 & $\begin{array}{l}1972 . \\
1973 .\end{array}$ & $\begin{array}{l}40 \\
40\end{array}$ \\
\hline
\end{tabular}

Note.-Based upon answers to the question, "Did you happen to attend church in the last seven days?" In 1947, the question was asked only of church members.

B. Average Frequency of Ghurch Attendance and Percentage of Believers in an Afterlife, by Religion, 1973

\begin{tabular}{|c|c|c|c|c|}
\hline Religion & $\begin{array}{c}\text { Sample } \\
\text { Size }\end{array}$ & $\begin{array}{l}\text { Average } \\
\text { Frequency } \\
\text { Religion }\end{array}$ & $\begin{array}{l}\text { Standard Deviation } \\
\text { in Annual Frequency } \\
\text { of Church Attendance }\end{array}$ & $\begin{array}{l}\text { Believe in } \\
\text { Afterlife } \\
(\%)\end{array}$ \\
\hline All Protestant & 940 & 27.77 & 31.84 & 76.06 \\
\hline Baptist . & 312 & 29.96 & 32.23 & 78.52 \\
\hline Episcopalian & 41 & 15.09 & 24.02 & 78.04 \\
\hline Lutheran ... & 124 & 22.27 & 25.12 & 70.97 \\
\hline Methodist. & 198 & 22.53 & 25.09 & 75.25 \\
\hline Presbyterian. & 57 & 27.14 & 26.80 & 68.42 \\
\hline Catholic ...... & 388 & 30.63 & 29.20 & 70.10 \\
\hline Jewish & 42 & 6.31 & 13.76 & 16.67 \\
\hline
\end{tabular}

Sources.-A: Historical Gallop Poll data cited in "Worship Habits Found Constant," New York Times, January 13, 1974; G. Gallup and J. Davies, Religion in America (Princeton, N.J.: American Inst. Public Opinion, 1971); Special Report on Religion 1967 (Princeton, N.J.: American Inst. Public Opinion, 1967); B. Landis, Religion in the United States (New York: Barnes \& Noble, 1965). B: Authors' calculations from the National Opinion Research Center's Spring 1973 General Social Survey data.

varies over time, different denominations use different criteria for defining what constitutes a member, and systematic underreporting of church members in certain groups or areas has occurred in each census. Consequently, substantial errors in the data are likely. Nevertheless, the table clearly indicates that the interstate variation in church-membership rates was large in each year, with the membership rate varying between roughly 30 and 70 percent. Any economic model of religious participation should contribute to the explanation of this phenomenon.

As noted in the introduction, sociologists have devoted much effort toward ascertaining the empirical correlates of various dimensions of religiosity, primarily using simple correlations or two-way tabular comparisons. In a properly specified multivariate model, not all of these correlations would necessarily be observed. However, it is important to ascertain whether a model of household allocation of time to market and 
TABLE 2

Church Membership as a Percentage of Population, by State

\begin{tabular}{|c|c|c|c|}
\hline & 1926 & 1936 & 1952 \\
\hline$\ldots \ldots \ldots \ldots \ldots \ldots \ldots \ldots$ & 37.4 & 37.9 & 41.2 \\
\hline 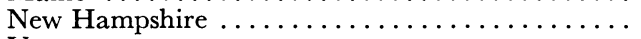 & 49.0 & 49.4 & 53.0 \\
\hline 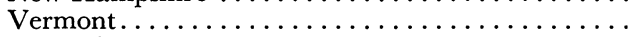 & 45.2 & 47.2 & 52.7 \\
\hline 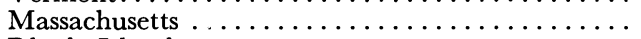 & 61.1 & 60.8 & 67.1 \\
\hline Rhode Island $\ldots \ldots \ldots \ldots \ldots \ldots \ldots \ldots$ & 69.1 & 67.4 & 75.7 \\
\hline 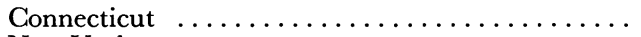 & 63.1 & 63.0 & 60.5 \\
\hline 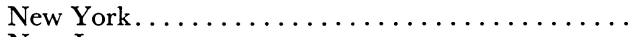 & 58.1 & 54.5 & 60.1 \\
\hline New Jersey. ................... & 53.8 & 57.3 & 57.6 \\
\hline 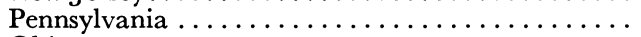 & 56.3 & 55.3 & 58.9 \\
\hline 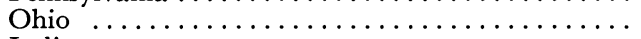 & 45.6 & 43.1 & 46.4 \\
\hline Indiana $\ldots \ldots \ldots \ldots \ldots \ldots \ldots \ldots \ldots$ & 44.4 & 40.3 & 43.6 \\
\hline Illinois $\ldots \ldots \ldots \ldots \ldots \ldots \ldots \ldots \ldots \ldots \ldots \ldots$ & 46.9 & 45.7 & 53.6 \\
\hline 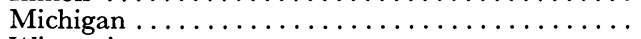 & 40.9 & 35.1 & 42.3 \\
\hline 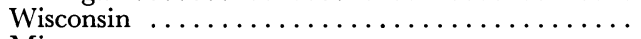 & 52.3 & 52.5 & 63.8 \\
\hline 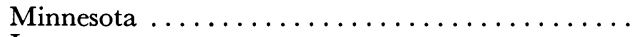 & 51.4 & 50.1 & 61.6 \\
\hline 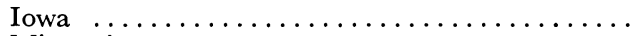 & 44.2 & 43.3 & 53.6 \\
\hline Missouri $\ldots \ldots \ldots \ldots \ldots \ldots \ldots \ldots \ldots \ldots$ & 44.7 & 37.4 & 48.9 \\
\hline 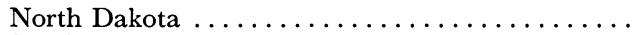 & 45.7 & 48.0 & 63.0 \\
\hline 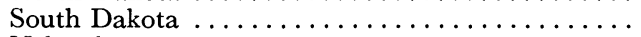 & 43.9 & 42.0 & 58.4 \\
\hline 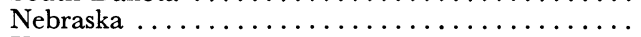 & 41.7 & 42.3 & 53.4 \\
\hline Kansas $\ldots \ldots \ldots \ldots \ldots \ldots \ldots \ldots \ldots$ & 40.7 & 37.7 & 46.6 \\
\hline 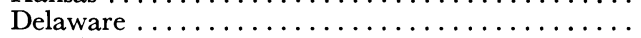 & 47.4 & 44.2 & 44.3 \\
\hline 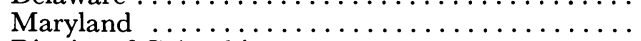 & 48.7 & 43.1 & 47.7 \\
\hline District of Columbia.................. & 51.1 & 45.8 & 46.6 \\
\hline 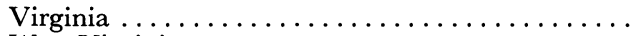 & 49.3 & 39.5 & 38.5 \\
\hline 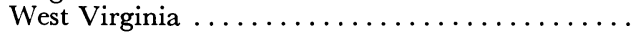 & 32.8 & 26.8 & 32.8 \\
\hline 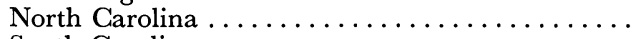 & 48.1 & 37.4 & 39.9 \\
\hline 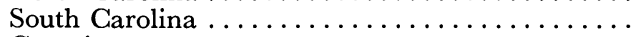 & 50.9 & 38.7 & 40.0 \\
\hline 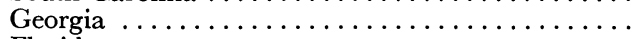 & 46.5 & 41.6 & 38.3 \\
\hline 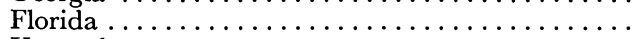 & 41.7 & 32.2 & 36.4 \\
\hline Kentucky $\quad \ldots \ldots \ldots \ldots \ldots \ldots \ldots \ldots \ldots \ldots \ldots \ldots$ & 41.5 & 33.2 & 44.8 \\
\hline 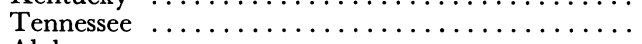 & 40.6 & 32.9 & 40.2 \\
\hline 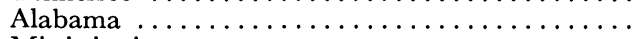 & 48.2 & 41.3 & 34.2 \\
\hline 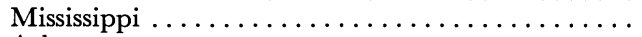 & 41.6 & 36.9 & 33.9 \\
\hline 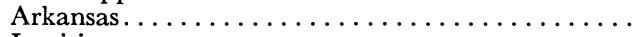 & 34.2 & 29.8 & 31.3 \\
\hline 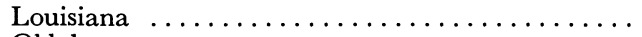 & 52.4 & 50.3 & 53.7 \\
\hline 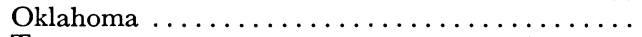 & 25.8 & 24.9 & 42.4 \\
\hline 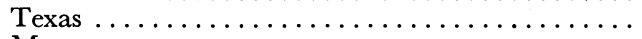 & 45.5 & 37.2 & 53.6 \\
\hline 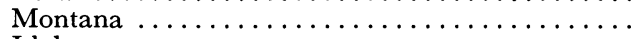 & 28.1 & 29.1 & 46.7 \\
\hline Idaho $\ldots \ldots \ldots \ldots \ldots \ldots \ldots \ldots \ldots$ & 37.0 & 36.2 & 44.1 \\
\hline Wyoming $\quad \ldots \ldots \ldots \ldots \ldots \ldots \ldots \ldots \ldots \ldots$ & 29.6 & 28.1 & 43.6 \\
\hline Colorado ...... & 35.4 & 32.6 & 41.6 \\
\hline New Mexico... & 54.2 & 49.9 & 64.9 \\
\hline Arizona ....... & 38.8 & 34.8 & 44.9 \\
\hline Utah & 76.3 & 69.9 & 73.3 \\
\hline 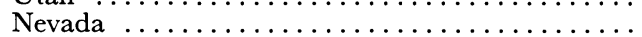 & 23.1 & 27.2 & 37.6 \\
\hline 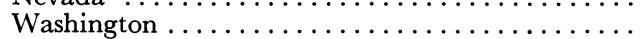 & 25.9 & 22.0 & 30.5 \\
\hline$\ldots \ldots \ldots \ldots \ldots \ldots \ldots \ldots$ & 26.3 & 24.1 & 27.7 \\
\hline California $\ldots \ldots \ldots \ldots \ldots \ldots \ldots \ldots$ & 31.9 & 30.1 & 40.7 \\
\hline U.S. average $\ldots \ldots \ldots \ldots \ldots \ldots \ldots \ldots$ & 44.6 & 41.4 & 49.2 \\
\hline
\end{tabular}

Sources.-Churches and Church Membership in the U.S. (New York: Nat. Council Ghurches of Christ USA, 1956), table 4; U.S. Bureau of the Census, Religious Bodies 1936 (Washington: Government Printing Office, 1941); 1940 Census of Population: Characteristics of the Population by State (Washington: Government Printing Office, 1942). 
nonmarket activities is capable of generating as implications all (or most) of these previously observed associations. Consequently, we list below some of the observed "regularities" that the sociological literature on the empirical correlates of religiosity has discovered. ${ }^{6}$

1. Women tend to participate in church-related activities more than men.

2. Church attendance tends to increase with age. However, some investigators have noted an initial decline with age until age 30-35, or a decline with age for the extreme elderly. The latter phenomenon is attributed to an increasing incidence of poor health.

3. Only weak relationships are found between income (or social class) and church attendance. Usually the relationship is positive, but some investigators find it backward bending (participation is highest for the middle-income groups).

4. Blacks attend church more frequently than whites.

5. Church attendance is higher in rural areas than urban areas.

\section{A Model of Household Religious Participation}

Individuals participate in church-related activities for at least three reasons. First, they may view their expected afterlife consumption as being related to their participation; we have previously referred to this as the "salvation motive." Second, they may derive current satisfaction from church membership and activities because of inherent religious beliefs or purely social reasons. We shall refer to this as the "consumption motive." Third, social pressures in a community may suggest that church membership and participation will increase the probability of an individual's succeeding in business. We shall refer to this as the "socialpressure motive," and it will probably be important in areas where only a few established churches exist, especially for new entrants to these communities. Although all three motives are undoubtedly present, our model will primarily consider the salvation motive, as strong testable implications are derived from the resulting framework. However, we shall indicate how the inclusion of the other motives alters the implications of the model.

We consider a household consisting of two members, a husband and a wife. The household is assumed to have a preference ordering that can be denoted by the quasiconcave utility function

$$
U=U\left(C_{1}, C_{2}, \ldots C_{t}, \ldots C_{n}, q\right)
$$

6 The list of regularities is derived from the sources cited in $\mathrm{n}$. 1 . In all cases the measure of religiosity used in these studies is closely related to either frequency of church attendance or time devoted to church-related activities. 
where $C_{t}$ represents the household's consumption in period $t$ and $q$ the expected value of the household's afterlife consumption. ${ }^{7}$ For simplicity, we assume that both household members know the length of their lives and that both will die at the end of period $n$. Both household members are also assumed to know their current and future market wages, which are taken as predetermined in the model. ${ }^{8}$

Household consumption in period $t$ is given by a household-production function which transforms the household's purchases of a composite market good $\left(x_{t}\right)$ and the time allocation by the husband $\left(h_{1 t}\right)$ and the wife $\left(h_{2 t}\right)$ to household consumption into units of the final consumption commodity $\left(C_{t}\right)$. For simplicity, we assume this function to be the same in each period and to be continuously differentiable and concave:

$$
C_{t}=C\left(x_{t}, h_{1 t}, h_{2 t}\right) \text { for all } t .
$$

Expected afterlife consumption is assumed to be believed by the household to be a continuous differentiable, concave function of the time spent in church-related (or devotional) activities by the husband $\left(r_{1 t}\right)$ and the wife $\left(r_{2 t}\right)$ in all periods during their lifetimes $:^{9}$

$$
q=q\left(r_{11}, r_{12}, \ldots r_{1 n}, r_{21}, \ldots r_{2 n}\right) .
$$

${ }^{7}$ Our household's view of the afterlife is not one of an all-or-nothing proposition (heaven or hell), it is rather that there exists a continuum of possible outcomes. The stream of expected afterlife benefits will last indefinitely into the future. However, if the household has any positive subjective rate of time preference, we can convert this infinite durational flow into a finite expected discounted present value of afterlife benefits (as of period $n+1$ ) which we denote by $q$. Thus, we can represent an infinite horizon model by an $n+1$ period model.

${ }^{8}$ The assumption that the time of death is known with certainty will be relaxed shortly. The assumption of exogenous wage implies that our model takes human-capitalinvestment decisions as predetermined, and it also abstracts from the time allocated to such investments. We consider the implications that can be derived when human-capital decisions are made endogenous in the concluding section of the paper.

9 This specification assumes that the expected afterlife benefits are shared by the household members and that they perceive the allocation of different members' time to religious activities as substitute inputs. The alternative assumption that each household member "produces" his own expected afterlife benefits can be shown to leave unaltered virtually all of the implications which we derive below. Equation (3) also ignores the possibility that individuals may substitute goods (charity) for time in the production of expected afterlife consumption. In the concluding section, we discuss the implications one obtains from allowing this possibility. We should emphasize that eq. (3) need be only perceived by the household to exist and need not in fact actually exist. One might reasonably question, however, if erroneous perceptions are likely to persist over time. Indeed, George Stigler has orally suggested to us that "the absence of evidence is not completely devoid of evidence." Nevertheless, for our purposes we need assume only that individuals perceive (3) to exist at a point in time. Finally the assumed concavity of the afterlife "production function" is easily justified. If the function were strictly convex, the result would be corner solutions, possibly with all of the household's time spent in religious activities. Individuals who display such behavior are in the minority, are not represented in our empirical data, and would not alter their behavior in response to marginal changes in the exogenous variables of the model. 
The precise specification of the function is of course determined by the beliefs of the household members. "Nonbelievers" are simply those individuals who believe that $q$ will always equal zero, regardless of the level of the household members' time inputs. In the context of this model, they would devote no time to religious activities. However, in more general models that allow for the consumption or social-pressure motives, their participation in religious activities would be rational.

Let $p$ denote the price of the market good in any time period, $w_{1 t}$ and $w_{2 t}$ the wage rates of the husband and wife, respectively, in period $t$, $i$ a constant market rate of interest, $v$ the household's exogenous nonlabor income in each period, and $l_{1 t}$ and $l_{2 t}$ the husband's and wife's hours of work in period $t$, respectively. Assuming that the household plans to leave no estate, its lifetime discounted income constraint is given by

$$
\sum_{t=1}^{n}\left[p x_{t} /(1+i)^{t-1}\right]=\sum_{t=1}^{n}\left[\left(v+w_{1 t} l_{1 t}+w_{2 t} l_{2 t}\right) /(1+i)^{t-1}\right] .
$$

If $T$ is the total time available per period, the time constraints it faces are given by

where

$$
h_{j t}+r_{j t}+l_{j t}=T \text { for } t=1,2, \ldots n \text { and } j=1,2,
$$

$$
x_{t}, h_{j t}, r_{j t}, l_{j t} \geq 0 \quad \text { for all } t \text { and } j .
$$

Statements (1)-(6) comprise a well-defined maximization problem. The production functions (2) and (3) can be substituted into (1) to yield a composite objective function, and the time constraints can be solved explicitly for $l_{1 t}$ and $l_{2 t}$ and substituted into (4) to yield a "full-wealth" constraint. Together, they allow one to write the Lagrangian function for the problem: ${ }^{10}$

$$
\begin{aligned}
L= & U\left[C\left(x_{1}, h_{11}, h_{21}\right), C\left(x_{2}, h_{12}, h_{22}\right), \ldots C\left(x_{n}, h_{1 n}, h_{2 n}\right),\right. \\
& \left.q\left(r_{11}, \ldots r_{1 n}, r_{21}, \ldots r_{2 n}\right)\right]+\lambda\left(\sum_{t=1}^{n}\left[p x_{t} /(1+i)^{t-1}\right]\right. \\
& \left.-\sum_{t=1}^{n}\left\{\left[v+\sum_{t=1}^{2} w_{j t}\left(T-h_{j t}-r_{j t}\right)\right] /(1+i)^{t-1}\right\}\right) .
\end{aligned}
$$

Assuming that an interior solution occurs, the first-order conditions require that at the optimum

$$
\left(\partial q / \partial r_{1 t}\right) /\left(\partial q / \partial r_{2 t}\right)=\left(w_{1 t} / w_{2 t}\right) \text { for all } t
$$

Suppose the husband and wife are equally efficient in the production of expected afterlife benefits in the sense that, if they both devote the same

${ }^{10}$ A mathematical appendix, available from Professor Ehrenberg, formally proves all of the propositions which follow. 
fraction of their time to religious activities in a period, their "marginal products" in expected afterlife-benefit production will be equal in that period. ${ }^{11}$ Equation (8) then implies that if their market wages are equal in the period they will devote the same number of hours to religious activities in the period; however, if the husband's wage exceeds the wife's wage in any period it implies that the wife will devote more hours to religious activities than will the husband. Thus a plausible explanation for women's more frequent participation in church-related activities is simply that they face lower market wages.

If we assume momentarily that both the husband and wife face constant market wage rates over their lifetimes, the first-order conditions can also be shown to require that at the optimum

$$
\left(\partial q / \partial r_{j t}\right) /\left(\partial q / \partial r_{j t-1}\right)=(1+i)^{-1} \text { for all } t \text { and } j=1 \text { or } 2 .
$$

This condition requires that household members reallocate their time toward church-related activities with advancing age. Indeed, if for an individual the marginal product of an additional hour of religious activity is the same in periods $t-1$ and $t$ when the individual devotes the identical number of hours to devotional activity during the two periods, then equation (9) implies that his number of hours per period devoted to religious activities should increase with age. ${ }^{12}$

The reason for this result should be obvious. Models of optimal accumulation of human capital show that it is optimal for individuals to concentrate their investment in human capital in the early stages of their life cycles since this will enable them to recoup the returns from the investments for a larger number of years. In contrast, the theory of investment in religious capital developed here implies that it is optimal to concentrate "investment" in the latter stages of the life cycle because the expected returns will not be generated until its end. The forces which generate a monotonically declining human-capital-investment profile with age will also generate a monotonically increasing "religious-capitalinvestment profile" with age.

This conclusion is based upon the assumption that wage rates of all household members are constant over their lifetimes. If for any two adjacent time periods ( $t$ and $t-1)$ an individual's wage rates vary, condition (9) becomes

$$
\left(\partial q / \partial r_{j t}\right) /\left(\partial q / \partial r_{j t-1}\right)=\left(w_{j t} / w_{j t-1}\right)(1+i)^{-1} \text { for } j=1 \text { or } 2 .
$$

${ }^{11}$ Formally, this requires $\left(\partial q / \partial r_{1 t}\right)=\left(\partial q / \partial r_{2 t}\right)$ when $r_{1 t}=r_{2 t}$. An example of one production function consistent with this assumption is

$$
q=\prod_{t=1}^{n}\left(r_{1 t}\right)^{1 / 2 n}\left(r_{2 t}\right)^{1 / 2 n}
$$

12 Formally, this requires $\left(\partial q / \partial r_{j t}\right)=\left(\partial q / \partial r_{j t-1}\right)$ when $r_{j t}=r_{j t-1}$. The production function suggested in the preceding footnote is consistent with this assumption. 
Consequently, ceteris paribus, the more rapid the rate of wage increase, the smaller will be the rate at which hours devoted to religious activity will increase with age. Since age-earnings profiles tend to be steeper for males than females, this condition suggests that age hours devoted to religious-activity profiles will be steeper for females than males. That is, females' hours devoted to religious activities will rise more rapidly with age than will comparable profiles for males because females' marginal cost of investing in religious capital rises less rapidly with age than males'.

If the rate of wage increase between any two periods is sufficiently large, it may "swamp" the effect of discounting and cause religious participation to decline between the two years. Age-earnings profiles tend to be concave, with the rate of increase in earnings declining with age. Consequently, especially for white males who show sharp earnings increase during their twenties, the age-religious-participation profile may be $\mathrm{U}$ shaped, first declining with age and then increasing, as some sociologists have observed.

The optimality conditions also enable us to calculate the impact on religious participation of a change in the household's exogenous nonlabor income or a proportionate change in an individual's wage rate each period. As long as expected afterlife consumption is a normal good, an increase in the level of exogenous nonlabor income will lead to an increase in religious participation, that is,

$$
\partial r_{j} / \partial v>0 \quad \text { for } j=1 \text { or } 2 .
$$

The response of an individual's time devoted to religious activities to a proportionate shift in his wage profile can be decomposed into the sum of an income-compensated own substitution effect $\left(\partial r_{j} / \partial w_{j}\right)^{*}$ and an income effect:

$$
\partial r_{j} / \partial w_{j}=\left(\partial r_{j} / \partial w_{j}\right)^{*}+l_{j} \partial r_{j} / \partial v \quad \text { for } j=1 \text { or } 2 .
$$

Under weak assumptions, the compensated substitution can be shown to be negative, while the income effect presumably is positive. ${ }^{13}$ Thus the uncompensated own substitution effect is unrestricted in sign.

13 The negative sign of the compensated substitution effect follows directly from two facts. First, the opportunity costs of an hour in consumption activity or an hour in religious activity are identical for an individual and equal to his wage rate. A compensated increase in the wage rate must therefore cause a decrease in the sum of nonmarket work hours. Second, religious activity is more time intensive than the consumption commodity, since market goods can be used to produce the latter. Consequently, an increase in the wage rate increases the cost of religious activity relative to the cost of the consumption commodity and induces the individual to substitute consumption for religious activity. Provided that the time utilized in household production increases as current consumption increases, the postulated result follows. Note that if we allowed goods (contributions or the explicit purchases of indulgences) to enter the afterlife-benefit-production function, the sign of the compensated substitution effect would depend upon the relative time intensities of $C$ and $q$. 
Our analysis so far has been restricted to a consideration of only the salvation motive for religious participation. ${ }^{14}$ It can be easily generalized, however, to include the consumption motive. That is, if because of either inherent religious beliefs or purely social reasons the household obtains current satisfaction from participating in religious activities, then the household utility function in ( 1 ) is replaced by

$$
U=U\left(C_{1}, s_{1}, C_{2}, s_{2}, \ldots C_{n}, s_{n}, q\right),
$$

where $s_{t}$ is the consumption value of religious participation in period $t$. It is assumed to be a continuous concave function of the husband's and wife's times devoted to religious activities during the period:

$$
s_{t}=s_{t}\left(r_{1 t}, r_{2 t}\right) \text { for all } t \text {. }
$$

If the husband and wife are equally efficient in the production of both current religious-consumption benefits and expected afterlife benefits, as long as her market wage is lower the wife will continued to spend a greater number of hours in religious activities. ${ }^{15}$ Our implications concerning the effects of exogenous nonlabor income and an individual's wage rate on religious participation can also be shown to remain unchanged. In contrast, the generalization of equation $\left(9^{\prime}\right)$ with regard to the intertemporal allocation of time to religious activities is given by

$$
\begin{aligned}
& \frac{\left(\partial U / \partial s_{t}\right)\left(\partial s_{t} / \partial r_{j t}\right)+(\partial U / \partial q)\left(\partial q / \partial r_{j t}\right)}{\left(\partial U / \partial s_{t-1}\right)\left(\partial s_{t-1} / \partial r_{j t-1}\right)+(\partial U / \partial q)\left(\partial q / \partial r_{j t-1}\right)} \\
& =\frac{w_{j t}}{w_{j t-1}}(1+i)^{-1} \quad \text { for all } t \text { and } j=1 \text { or } 2 .
\end{aligned}
$$

Even if an individual faces a constant wage rate during the two periods, there may no longer be any a priori basis for concluding that participation should increase with age because of the consumption motive for religious participation. However, if the salvation motive is substantially more important to individuals than the consumption motive, all of our previous

${ }^{14} \mathrm{~A}$ referee has pointed out to us that the salvation motive operates in our model in an analogous manner to the bequest motive in models of optimal consumption over time. However, the usual models stress bequests as functions of goods, not of time inputs. The recent work on preschool investment in children, for example Leibowitz (1974), is somewhat similar analytically to our approach in that it involves a bequest of human capital which is created at least partially through time inputs. A second referee has questioned whether the salvation motive is really a major motive for religious participation, citing a study (Croog and Levine 1972) that found that men experiencing a myocardial infarction (heart attack) show virtually no change in their frequency of attendance at religious services over a course of a year following the crisis event. This study was based upon a sample of 324 men and relied primarily on simple tabular comparisons. Rather than argue about the importance of this motive a priori, we prefer to stress the testable implications that it generates and our empirical results which follow.

15 That is, in addition we now require that $\left(\partial s_{t} / \partial r_{1 t}\right)=\left(\partial s_{t} / \partial r_{2 t}\right)$ when $r_{1 t}=r_{2 t}$ for all $t$. 
implications concerning age-religious-participation profiles are likely to continue to hold. ${ }^{16}$

Clearly any factor which increases the current satisfaction which the household receives from participating in religious activities should lead to an increase in the time it allocates to church activities. For example, since market consumption alternatives are relatively limited in rural as opposed to urban areas, the social values of religious activities are probably higher in rural areas, and thus religious participation is higher there. Similarly, racial discrimination may take the form of limiting market consumption alternatives of nonwhites relative to whites and thus lead to higher nonwhite religious participation. In addition, factors such as whether both husband and wife are members of the same religion and the number of school-age children in a family should influence the current consumption value of religious activities and, therefore, the household's religious participation. ${ }^{17}$ We should emphasize, though, that observed empirical relationships between the variables discussed in this paragraph and religious participation are not strong tests of the model since they follow solely from the assumption of systematic variations in preferences. Rather, they are entered in our empirical analyses primarily as control variables.

Finally, all of the implications we have derived under the assumption that the household's time of death is certain can be derived in a model in which the time of death is uncertain. Specifically, if we assume that the husband and wife die at the same time, that the probability of the household's death in early periods is small, and that expected afterlife consumption starts in period $n+1$ regardless of the household's time of death, then all of our results follow. Once the probability of death in a period becomes relatively large, however, we may observe religious participation declining with age. That is, once an individual is faced with a relatively high probability of death in a period it may become optimal for him to concentrate his religious participation as early as possible, since he may not survive to "invest" in future periods. Thus, the introduction of an uncertain time of death leads to the possibility of declining age-religious-participation profiles for the aged. ${ }^{18}$

${ }^{16}$ Formally this would require $\partial u / \partial q$ to be substantially larger than $\partial u / \partial s$ for all $t$. If it were not and if $\partial u / \partial s_{t}$ were sufficiently small relative to $\partial u / \partial s_{t-1}$, then at the optimum $r_{j t}<r_{j t-1}$. A sufficient condition for $r_{j t}>r_{j t-1}$ is that the production functions for $s_{t}$ be the same in all periods and $\left(\partial u / \partial s_{t}\right)\left(\partial u / \partial s_{t-1}\right) \leq(1+i)^{-1}$.

${ }^{17}$ Clearly the social-pressure motive for religious participation can be incorporated into the model in an analogous manner. However, except for the observation that this motive is likely to be more important in rural than urban areas, it appears difficult to specify important variables we possess which will influence it.

18 Models in which the "date of salvation" was also a random variable were also experimented with; however it proved impossible for us to derive any implications from them. 


\section{Empirical Estimates}

We present econometric tests of the implications of the model below using two types of data: statewide church-membership data for 1952, 1936, and 1926; and survey data on the annual frequency of church attendance for approximately 1,500 U.S. adults in 1973. We caution that the model yields implications concerning the total time devoted to religious activities, and this is unlikely to be perfectly correlated across individuals (or states) with the annual frequency of church attendance (or church membership). For example, in some religions prayer in the home is a substitute for formal church attendance. Nevertheless, these two types of data are the closest available proxies for the desired dependent variable.

\section{A. Church-Membership Equations}

Church-membership data is notoriously poor in quality. Since 1916 four censuses have been attempted, the first three $(1916,1926,1936)$ by the U.S. government; the last (1952) by the National Council of the Churches of Christ in the United States of America. All suffer from reporting errors and incomplete coverage. The latter census, based upon data reported through national religious organizations, does not contain data for a number of Negro churches; thus church-membership figures are substantially underestimated in 1952 for states with relatively large black populations. The government census data was derived from questionnaires mailed to local churches. Although no explicit mention is made of systematic reporting errors in any of the census volumes, it appears that due to incomplete coverage or differential response rates church membership in rural areas and among the black population may have been underestimated in these years.

The definition of what constituted a church member also differed across religions and over time. The Catholic church considered all people who had been baptized, including infants, as members in all four years. Most Protestant sects reported only adult members (usually over age 13). For the last three sets of data, the Jewish membership figures reflected a "cultural count," the approximate number of Jews living in communities with a synagogue independent of their actual synagogue affiliation. In 1916, however, only Jewish male heads of households were reported as members. Clearly, reported membership rates varied across states simply because of variations in the religious composition of the population.

In spite of the questionable quality of the data, we have estimated cross-section regression equations for each year in an attempt to explain the interstate variations in church-membership rates. The explanatory variables which are directly related to our model include measures of the 
age and sex structure of the state's population, measures of male and female average wage rates, and measures of nonlabor income or wealth. To control for the measurement errors in the reported church-membership-rate variable, we also include as explanatory variables the percentages of a state's reported church members who are Catholic and Jewish, the percentage of a state's population that is nonwhite, and the state's population density. ${ }^{19}$

The first two rows of table 3 present estimates based upon the 1952 data with all variables entered in linear form, while the last two rows contain estimates based upon a logit transformation of the dependent

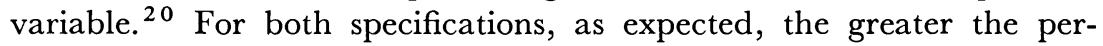
centage of the population that is female, the higher the church-membership rate. The wealth variable measured either by median family income or the median value of owner-occupied housing also has a positive effect. Both the male- and female-wage variables, as measured by the median earnings of full-year workers, have negative effects on church-membership rates. Finally, the median-age variable is positively related to churchmembership rates. ${ }^{21}$ All of these relationships are statistically significant and conform to the predictions of our model. Furthermore, each of the control variables which is statistically significant has the anticipated sign.

Similar estimates for the 1936 and 1926 data are found in columns 1-8 of table $4 .^{22}$ Unfortunately, separate wage data for males and females are unavailable for those years, and a composite wage variable-average annual earnings of manufacturing employees in the state-is used instead. Quite strikingly, we again observe significant positive wealth or (nonlabor) income coefficients and significant negative wage coefficients for both years, in accordance with the model's predictions.

In contrast with the previous results, increases in the median age of the population are associated with lower church-membership rates in 1936 and 1926, while increases in the proportion of the population over

19 The latter two variables are replaced by the white proportion of the state's population and the proportion of the population residing in urban areas, for years prior to 1952. Since these variables are included to control for systematic measurement errors in the reported state membership data, we are unable to test if membership rates actually vary systematically with these variables, as our model with the consumption motive included would predict. Our wage-rate variable is actually the product of the wage rate and annual hours of work, and hence may also be subject to systematic measurement errors.

20 We include the latter form because the linear specification does not restrict the predicted value of the dependent value to lie in the $(0,1)$ range. Since qualitatively the estimates are identical for both specifications, we report only the linear specification in later tables.

${ }^{21}$ The negative coefficient for the fraction of the population greater than age 65 may reflect either the high probabilities of death or poorer health of this group.

22 Similar equations were estimated using the 1916 data, but significant measurement errors present in that year's independent variables lead to primarily statistically insignificant (and biased) coefficients. We thus have omitted the reporting of these results. 
TABLE 3

Church-Membership Equations, 1952 (Absolute Value $t$-Statistics

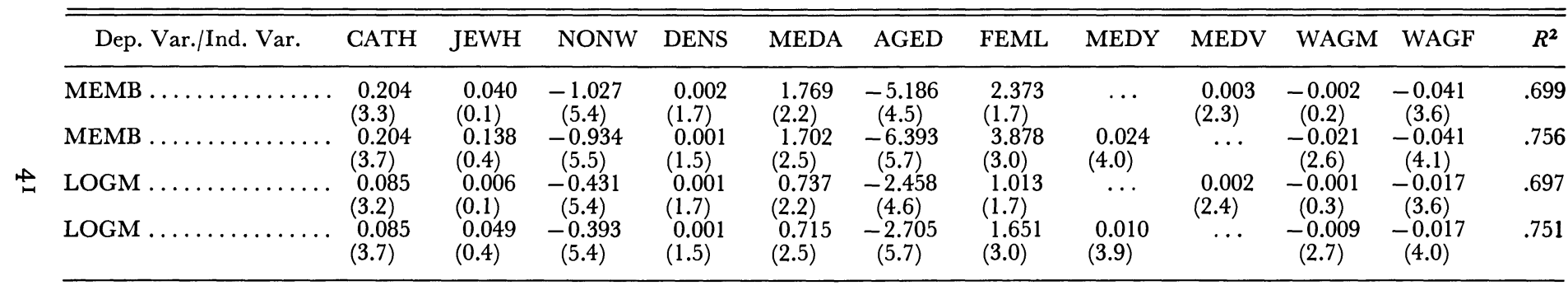

Sources.-All variables (except for the church-membership data) are reported for 1950 and calculated from Churches and Church Membership in the U.S. (New York: Nat. Council Churches of Christ USA, 1956); U.S. Bureau of the Census, County and City Data Book 1952 (Washington: Government Printing Office, 1953); 1950 Census of Population: Characteristics of the Population (Washington: Government Printing Office, 1952).

Note. $-n=49$ for all equations. All LOGM coefficients have been multiplied by a factor of 10 . MEMB $=$ percentage of state population that is church members; CATH $=$ percentage of church members that are Catholic; JEWH $=$ percentage of church members that are Jewish; NONW $=$ percentage of state population that is nonwhite; DENS $=$ state population density; MEDA = median age of the state population; AGED = percentage of the state population age 65 and older; FEML = percentage of the state population that is female; MEDY = median family income in the state; MEDV $=$ median value of owner-occupied housing in the state; WAGM = median annual earnings of male full-year workers;
WAGF = median annual earnings of female full-year workers; LOGM = logarithm of (MEMB/1 - MEMB). 
TABLE 4

Church-Membership Equations, 1936 and 1926 (Absolute Value $t$-Statistics)

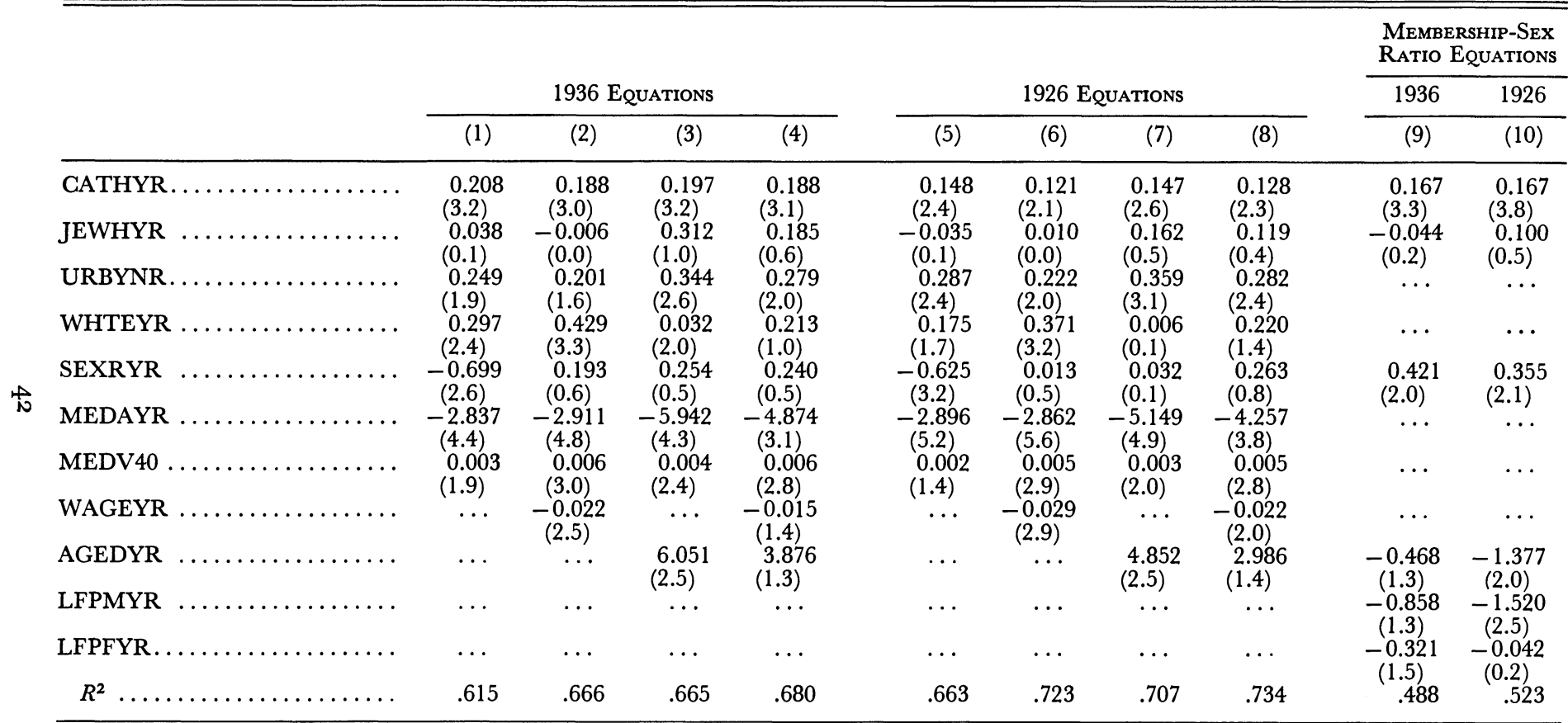

Sources.-All variables are calculated from data in the following sources available from the Government Printing Office, Washington: U.S. Bureau of the Census, Religious Bodics 1936 (1941); Religious Bodies 1926 (1930); 1940 Census of Housing: General Characteristics (1943); 1940 Census of Population: Characteristics by Age (1943); 1940 Census of Population: Characteristics of the Population by State (1943); 1935 Biennial Census of Manufacturers (1938); 1925 Biennial Census of Manufacturers (1928).

Note. $-N=49$ for all equations. CATH = percentage of state church members that are Catholic; JEWH $=$ percentage of state church members that are Jewish; URBN = percentage of state population in urbanized areas; WHTE = percentage of state population that is white; $\mathrm{SEXR}=$ males/100 females in the state; MEDA = median age of the populaolder than age 65; LFPM = male labor force participation rate; LFPF = female la yearly earnins of manufacturing production workers; AGED = percentage of the population of the dependent variable. 
age 65 lead to increases in the membership rate each year. These results are consistent with our model since the median age in both years in most states was less than 30 years, which may well lie in the downwardsloping stage of the age-participation profile. This does not explain, however, why the median-age and "aged"-population coefficients estimated from the 1952 data had the opposite sign pattern. ${ }^{23}$

Similar to the 1952 results, increases in the ratio of males to females is seen to decrease church membership in both 1936 and 1926 (eqs. [1] and [5]), as predicted by our model. However, the addition of either the wage variable or the percentage of the population older than 65 to the equation causes this variable to lose its significance. The average-wage variable is highly correlated with the sex-ratio variable, and this may have led to collinearity problems. ${ }^{24}$

Finally, in columns 9 and 10 of table 4 we present estimates of equations which seek to explain why the ratio of male/female church members varies across states. Not surprisingly, the male/female population ratio is an important determinant of the membership ratio. Moreover, in at least one year, 1926, increases in the male labor force participation rate also led to decreases in the male/female membership ratio. In contrast, the female labor force participation rate does not appear to influence the membership ratio. ${ }^{25}$

Overall, these results are mixed. The 1952 data, in which we have the most confidence, strongly support our model. However, the 1936 and 1926 census data, while supporting the existence of income and substitution effects on religious participation, are more ambiguous about the existence of age and sex effects. To ascertain if the latter exist, we turn to a study of variations in the frequency of church attendance across individuals.

\section{B. Frequency-of-Church-Attendance Equations}

The Spring 1973 General Social Survey conducted by the National Opinion Research Center contains data for a sample of 1,504 U.S. adults, including

${ }^{23}$ The sign reversal may be due to the high positive correlation between the two age variables in each year. As is well known, collinearity does not cause biased coefficient estimates. However, it does cause coefficient estimates to become very sensitive to the particular set of sample data used. Moreover, if two variables are highly positively correlated, the deviations of the estimated coefficients from their true values are likely to be equal and opposite in sign (see Johnson [1972, pp. 160-62] for an elaboration of these points).

24 This correlation is a mechanical one, as an increase in the proportion of males in a state will lead to an increase in the observed average wage because males receive higher wages than females.

25 The labor force participation rates are used as imperfect proxies for the unavailable wage-rate data by sex. Their use also leads to possible simultaneous equation bias. Unfortunately, while separate wage data by sex is available for 1952, church-membership data by sex is not. 
their reported annual frequencies of church or synagogue attendance. Individuals in the sample were also asked if they believed in a life after death. Approximately 76 percent of the Protestants, 70 percent of the Catholics, and 17 percent of the Jews responded affirmatively to this question (table 1B). The inclusion of these two questions makes this survey the best available source of data to empirically test our model; however it has several important weaknesses, which we note below.

Ideally, one would like to estimate an empirical model in which the frequency of church attendance of both the husband and wife are simultaneously determined. Unfortunately, frequency of church attendance is reported in the survey only for the individual respondents and not for their spouses. We are thus limited to explaining variations in church attendance across individuals. A sufficient number of "familybackground" variables is reported by each individual, however, to enable us to specify an estimating equation that represents a reduced-form equation derived from our household model.

The second major weakness of the survey is its failure to include any information on market wage rates of the household members. Instead, information is provided on the Hodge-Siegel-Rossi occupational prestige index for the respondent and his (her) spouse, based on the census twodigit occupations in which they are employed. This index is a rating of occupational titles made by a national sample of the American population. The ratings tend to be stable over time, and for both 1960 and 1970 census data the correlation between mean annual income in an occupation and the prestige index exceeded $.70 .^{26}$ As such, they may be considered extremely crude proxies for the relative market wage rates of individuals, abstracting from the individuals' positions in their life cycles. Clearly, substantial measurement errors are involved in the use of these proxies, and, making standard assumptions, one can show that their coefficients will be biased toward zero.

The survey data permit us to specify an estimating equation in which an individual's annual frequency of church attendance is related to variables predicted by the model to influence church attendance as well as a set of control variables. The former include the individual's age and sex, the occupational prestige scores for the respondent and spouse, family income, and whether the individual believes in an afterlife. ${ }^{27}$ The control variables include the respondent's race, whether the spouse

26 The multiple correlation using both census mean annual income and median education level in the occupation is about .86. This information, as well as the description of the Hodge-Siegel-Rossi occupational prestige index in the text, was kindly provided to us by Peter Rossi in private correspondence dated October 29, 1973.

${ }^{27}$ Family income was reported in 12 discrete intervals. We constructed a continuous variable by assigning to each household a family income equal to the midpoint of the interval in which the household's family income was located. In the calculation of the estimates reported in the text, we arbitrarily assigned a family income of $\$ 30,000$ to the approximately 6 percent of the households whose incomes fell in the open interval of 
is of the same major religion, the number of children between the ages of six and 18 in the household, the number of children younger than age six in the household, and a set of dichotomous variables which indicate how the individual rates his (her) health.

The first three control variables are included to capture factors which influence the current utility the household receives from participating in religious activities. That is, the social value of religious activity is probably higher for racial minorities, as discrimination may limit their market consumption alternatives; for families in which both spouses are of the same religion; and for families with school-age children. In contrast, the presence of preschool-age children or an individual's being in poor health are likely to increase the cost of church attendance to the individual and thus reduce his frequency of attendance. The latter variable may also influence frequency of church attendance if it is associated, ceteris paribus, with higher probabilities of death. In this case, it may be optimal for the individual to concentrate his religious participation as early as possible. ${ }^{28}$

Table 5 presents estimates of this empirical church-attendance equation for five subsamples of the data consisting of all Protestants, Catholics, Methodists, Lutherans, and Baptists, respectively. ${ }^{29}$ These regressions are not restricted to the set of families in which two spouses are present and earning labor income, as our theoretical model assumes. The imposition of such restrictions would reduce each subsample to approximately one quarter of its original size, leaving us only limited degrees of freedom. However, as the last column of the table indicates, imposing these restrictions for the large all-Protestant sample and reestimating the equation did lead to results which are quite similar to those found in the unrestricted sample. ${ }^{30}$

The estimates presented in table 5 provide, in the main, strong support for our theory. Frequency of attendance increases with age $\left(x_{1}\right)$ for all groups. Females attend church more frequently than males $\left(x_{2}\right)$ and nonwhites more frequently than whites $\left(x_{3}\right)$. Belief in an afterlife $\left(x_{4}\right)$ is quantitatively a major determinant of church attendance for all groups,

$\$ 25,000$ or greater. Regressions were also estimated in which we assigned these families incomes of $\$ 44,000$, the figure estimated by Miller (1963) to be the mean income in the open interval; however, the estimated coefficients were virtually identical with those reported in the text. Finally, we included a $(1,0)$ variable in the estimating equations in an attempt to control for the approximately 7 percent of the sample who failed to report their family incomes.

28 Preliminary estimates indicated that, ceteris paribus, region of the country, ruralurban dichotomy, and marital status per se (independent of its influence on other variables) did not significantly influence frequency of attendance. These variables are thus not included in the regressions reported in the text.

29 Equations were also estimated for subsamples consisting of Jews, Episcopalians, and Presbyterians. Due to the relatively small subsample sizes (table 1B), most coefficients proved to be statistically insignificant. Consequently, these results are not reported in the text.

30 Similar results were found for the other religious groups. In each case, when a coefficient estimate remained statistically significant when the relatively small restricted sample was used, its sign was the same as that reported in table 5. 
TABLE 5

Frequency of Church-Attendance Regressions (Absolute Value $t$-Statistics)

\begin{tabular}{|c|c|c|c|c|c|c|}
\hline Variable & Protestant & Catholic & Methodist & Lutheran & Baptist & Protestant B \\
\hline$x_{1} \ldots \ldots \ldots \ldots \ldots \ldots \ldots \ldots \ldots$ & $\begin{array}{l}0.233 \\
(3.4)\end{array}$ & $\begin{array}{l}0.369 \\
(3.7)\end{array}$ & $\begin{array}{l}0.254 \\
(2.0)\end{array}$ & $\begin{array}{l}0.243 \\
(1.5)\end{array}$ & $\begin{array}{l}0.310 \\
(2.4)\end{array}$ & $\begin{array}{l}0.343 \\
(1.7)\end{array}$ \\
\hline$x_{2} \ldots \ldots \ldots \ldots \ldots \ldots \ldots \ldots \ldots$ & -7.241 & -12.875 & -7.179 & -9.062 & -17.373 & -10.559 \\
\hline 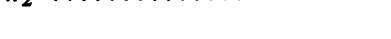 & $(3.4)$ & $(4.4)$ & $(1.9)$ & (1.8) & $(4.6)$ & (2.5) \\
\hline$x_{3} \ldots \ldots \ldots \ldots \ldots \ldots \ldots \ldots$ & -8.825 & -0.255 & -5.242 & -26.261 & -0.342 & -23.412 \\
\hline & $(3.2)$ & $(0.1)$ & $(1.0)$ & (1.1) & $(0.1)$ & (3.9) \\
\hline$x_{4} \ldots \ldots \ldots \ldots \ldots \ldots \ldots$ & 21.044 & 13.661 & 14.889 & 16.521 & 16.849 & 25.896 \\
\hline (1) & (9.1) & $(4.5)$ & $(3.6)$ & $(3.3)$ & $(3.9)$ & $(5.2)$ \\
\hline$x_{5} \ldots$ & 6.281 & 11.539 & 7.393 & -2.186 & 10.808 & -4.141 \\
\hline 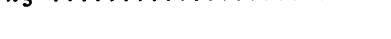 & $(2.4)$ & $(3.5)$ & $(1.4)$ & $(0.5)$ & $(2.2)$ & $(0.6)$ \\
\hline$x_{6} \ldots$ & 7.907 & -1.655 & 17.156 & -4.041 & 7.165 & 22.446 \\
\hline 0 & $(1.7)$ & $(0.3)$ & $(1.9)$ & $(0.4)$ & $(1.0)$ & $(1.5)$ \\
\hline$x_{7} \ldots \ldots \ldots \ldots$ & $9.853\left(10^{-4}\right)$ & $0.087\left(10^{-4}\right)$ & $2.674\left(10^{-3}\right)$ & $1.819\left(10^{-3}\right)$ & $2.304\left(10^{-4}\right)$ & $2.534\left(10^{-3}\right)$ \\
\hline$x_{0} \ldots$ & $\begin{array}{l}(1.8) \\
-5.506\end{array}$ & $\begin{array}{c}(0.4) \\
-8.563\end{array}$ & $\begin{array}{c}(2.6) \\
-1.753\end{array}$ & $\begin{array}{c}(1.4) \\
-2.482\end{array}$ & $\begin{array}{l}(0.7) \\
-9.114\end{array}$ & $\begin{array}{l}(1.7) \\
-9.549\end{array}$ \\
\hline$x_{8} \cdots$ & $(2.3)$ & $(2.6)$ & $(0.4)$ & $(0.4)$ & $(2.0)$ & $(2.0)$ \\
\hline$x_{9} \ldots \ldots \ldots \ldots \ldots \ldots \ldots$ & $\begin{array}{l}-5.813 \\
(2.0)\end{array}$ & $\begin{array}{c}-14.911 \\
(3.7)\end{array}$ & $\begin{array}{l}2.413 \\
(0.5)\end{array}$ & $\begin{array}{c}-9.092 \\
(1.4)\end{array}$ & $\begin{array}{c}-11.573 \\
(2.2)\end{array}$ & $\begin{array}{c}-10.803 \\
(1.7)\end{array}$ \\
\hline$x_{10} \ldots \ldots \ldots \ldots$ & -4.683 & -21.654 & -5.178 & -0.469 & -9.071 & 3.596 \\
\hline 10 & (1.1) & $(3.8)$ & $(0.7)$ & $(0.1)$ & $(1.2)$ & $(0.3)$ \\
\hline$x_{11} \ldots \ldots \ldots$ & 0.035 & 0.067 & -0.027 & 0.196 & 0.097 & 0.317 \\
\hline & $(0.6)$ & $(0.7)$ & $(0.3)$ & $(1.4)$ & $(0.9)$ & $(2.1)$ \\
\hline$x_{12} \ldots \ldots \ldots \ldots \ldots \ldots \ldots$ & -0.025 & -0.081 & -0.095 & 0.097 & -0.238 & 0.116 \\
\hline & $(0.4)$ & $(1.1)$ & $(0.9)$ & $(0.8)$ & $(1.9)$ & $(0.7)$ \\
\hline$x_{13} \ldots \ldots \ldots \ldots \ldots \ldots \ldots$ & 0.024 & -1.223 & -6.163 & -2.122 & -1.500 & 1.742 \\
\hline & $(0.1)$ & $(0.6)$ & $(1.7)$ & $(0.7)$ & $(0.6)$ & $(0.5)$ \\
\hline$x_{14} \ldots \ldots \ldots \ldots \ldots \ldots \ldots$ & 1.822 & 0.845 & 0.932 & 0.552 & 2.989 & 2.836 \\
\hline & (2.3) & $(0.8)$ & $(0.6)$ & $(0.3)$ & $(2.3)$ & $(1.7)$ \\
\hline$x_{15} \ldots \ldots \ldots \ldots \ldots \ldots \ldots$ & $-3.507\left(10^{-8}\right)$ & $\cdots$ & $-8.815\left(10^{-8}\right)$ & $-8.155\left(10^{-8}\right)$ & $\ldots$ & $-9.749\left(10^{-8}\right)$ \\
\hline$D^{2}$ & $(1.9)$ & & $(2.6)$ & $(1.7)$ & & (2.1) \\
\hline$R^{2}$ & .138 & .201 & .177 & .241 & .171 & .247 \\
\hline$N$. & 940 & 388 & 198 & 124 & 312 & 221 \\
\hline
\end{tabular}

Note.-Males and females treated symmetrically, i.e., if a female is being interviewed, the spouse refers to a male. Protestant B sample restricted to households in which both spouses are present and working. $x_{1}=$ age; $x_{2}=$ male $=1$, female $=0 ; x_{3}=$ white $=1$, nonwhite $=0 ; x_{4}=$ believe in afterlife, yes $=1$, no or uncertain $=0 ; x_{5}=$ spouse is of same religion; $x_{6}=$ no income data reported for family of $(1,0) ; x_{7}=$ family income: $x_{8}=$ respondent rates health as good $(1,0) ; x_{9}=$ respondent rates health as fair $(1,0) ; x_{10}=$ respondent rates health as poor $(1,0) ; x_{11}=$ Hodge-Siegel-Rossi occupational prestige score; $x_{12}=$ spouse's occupational prestige score; $x_{13}=$ number of children under age $6 ; x_{14}=$
number of children ages $6-18 ; x_{15}=$ family income squared. 
and having a spouse of the same major religion $\left(x_{5}\right)$ significantly increases religious participation for most groups. ${ }^{31}$

Individuals in the sample rate their health status as excellent, good, fair, or poor. Dichotomous variables were defined for the latter three categories and entered into the regressions $\left(x_{8}, x_{9}, x_{10}\right)$. Compared with those individuals in excellent health, other individuals tend to have reduced church attendance, as expected. ${ }^{32}$ Similarly, when their coefficients are statistically significant, an increase in the number of preschool-age children $\left(x_{13}\right)$ present reduces church attendance, while an increase in the number of school-age children $\left(x_{14}\right)$ present increases the frequency of attendance.

The coefficients of the individual's $\left(x_{11}\right)$ and spouse's $\left(x_{12}\right)$ occupational prestige indices, which serve as proxies for their market wages, are insignificant, in the main. ${ }^{33}$ This is not surprising; substantial measurement errors are likely to be present, as we are asking the national mean annual income in a broad two-digit occupation to serve as a good estimate of an individual's actual hourly wage. Moreover, the indices take on the value of zero for those individuals (or spouses) not currently employed, thereby assigning a zero opportunity cost of time to those engaged solely in nonmarket activity. ${ }^{34}$

${ }^{31}$ We face a possible simultaneity problem here because frequency of church attendance may influence an individual's belief in an afterlife. A structural model would thus have attendance influencing belief as well as vice versa. The resulting reduced-form "attendance equations" would be similar to those estimated in table 5, except that "belief" would be omitted. We have estimated such equations; the results are found in table Al. Although in all cases the explanatory power of the model falls with the omission of the belief variable, the coefficient estimates of the other variables appear quite similar to those found in table 5 .

32 The primarily insignificant coefficient for the "poor-health" variable $\left(x_{10}\right)$ may indicate that only for this group is the impact of the increased "cost" of attendance offset by a higher probability of death.

33 The one significant coefficient is a negative coefficient on spouse's status in the Baptist equation. A plausible, but not the sole, explanation for such a result is as follows: For wives who are respondents and are not in the labor force, an increase in the spouse's wages increases the market-goods available to combine with their own time in household production, thereby increasing the value of their time spent in household production relative to time spent in religious participation. This should induce them to reduce their religious participation. This argument refers to a corner solution, while our approach in the text considers only interior solutions. For more complete discussions of how a husband's wage income influences the value of a wife's time in home production, see Gronau (1973) and Willis (1973).

34 The only other available proxies for the opportunity costs of time are the education levels of the respondents and their spouses. Equations were estimated, substituting these variables for the occupational prestige indices. In the main, the coefficients of the other variables in the analysis were unchanged. When their coefficients were significant, the respondent's education level (two cases) had a positive impact on attendance while the spouse's education level (one case) had a negative impact. Education levels may influence nonmarket production via channels other than through their impact on wages (see Michael 1973), so these results should not be considered strong evidence in favor of (or against) our approach. 
In table 5, total family income is allowed to influence annual frequency of church attendance in a nonlinear way, as both income and income squared are present. For all Protestants, Methodists, and Lutherans, we observe statistically significant backward-bending relationships between frequency of attendance and total family income. That is, church attendance first increases and then decreases with family income; the maximum frequency occurring at about $\$ 14,000, \$ 15,000$, and $\$ 11,000$ for the all Protestants, Methodists, and Lutherans, respectively. On the other hand, frequency of church attendance is always positively but statistically insignificantly related to family income for Catholics and Baptists. ${ }^{35}$

If we interpret variations in total family income as being solely due to variations in wage rates, then both of these patterns would be consistent with our model. ${ }^{36}$ Unfortunately, variations in total family income may be due to variations in household wage rates, hours of work, number of family members employed, or nonlabor income. The data do not permit us to separate out all of these sources of variation. Consequently, the association between total family income and church attendance should not in itself be considered strong support for our approach. However, we reemphasize here the significant relationship between church-membership rates and income and wage variables that were found using statewide membership data in the preceding section.

The estimates so far presented constrain the shape of age-religiousparticipation profiles to be linear and to be identical for males and females. However, a strong implication of our model is that females' hours devoted to religious activities will rise more rapidly with age than will the comparable profile for males because males' age-earnings profiles tend to be steeper than females', Moreover, for males who show sharp earnings increases during their twenties, age-religious-participation profiles may be $\mathrm{U}$-shaped, first declining with age and then increasing. However, for females who have relatively flat age-earnings profiles, our theory would rule out an initial declining segment of the age-religious-participation profile.

To test for these differences in the shape of age-religious-participation

${ }^{35}$ Formally, adding the square of family income to the estimating equation does not significantly increase the explanatory power of the model for the Catholic and Baptist subsamples. The interpretation requires us to assume that the occupational prestige indices do not capture variations in market wages.

${ }^{36}$ Suppose that both the income effect and compensated substitution effect of a wage change may be treated as parameters. If an individual is on the backward-bending segment of his market labor supply curve and the income effect weighted by market hours is initially larger in absolute value than the substitution effect, we will observe a backwardbending religious-participation function, first increasing and then decreasing as the individual's wage rate increases. On the other hand, if the individual is on the upwardsloping segment of his market labor supply curve and the income effect weighted by market hours initially is larger than the substitution effect in absolute value, then we will observe a positive relationship between his wage and his religious participation. 
profiles, the equations presented in table 5 were reestimated adding age squared as an explanatory variable and allowing the coefficients of this variable and age to vary by sex. Based upon the residual sum of squares from these equations and those found in table 5, formal $F$-statistics were calculated to test the null hypothesis that age-religious-participation profiles are linear and their slopes do not vary by sex. The results are tabulated in the first column of table 6; the null hypothesis is rejected for three of the five religion categories.

The remaining columns of table 6 present the actual estimated coefficients of the age and age squared variables, by sex, for these three religion categories. Also presented is the estimated "turning age" for each religion-sex group and the estimated "overtaking age" for each religion. The former is the age at which the frequency of church attendance reaches a minimum (or maximum) for a group; the latter indicates the age until which the slope of the age-frequency-of-church-attendance profile is steeper for females than for males. ${ }^{37}$

Most strikingly, we observe that for all three groups the overtaking age does not occur until about age 50. That is, throughout the region in which male age-earnings profiles tend to be steeper than female ageearnings profiles, the slope of the age-church-attendance profile is steeper for females than males as our theory predicts! Moreover, for two of the three male groups, church attendance is always increasing with age, while for the third group we observe a U-shaped profile. In contrast, we note that none of the female groups exhibits an initial range of religious participation declining with age. Taken together, these results provide additional strong support for our theory. ${ }^{38}$

\section{Concluding Remarks}

This paper represents the first systematic attempt by economists to analyze the determinants of religiosity, individuals' religious commitment and participation in church-related activities. A multiperiod utilitymaximization model of household allocation of time has been developed which suggests the determinants of household religious participation and includes implications about the division of participation between

37 Given the lack of statistical significance of most of the individual regression coefficients used in the calculations, these estimates are subject to substantial error and should be interpreted accordingly.

38 Each female group's frequency of attendance reaches a peak around age 60, which is not directly predicted by a model that includes only the salvation motive. The declining profile may reflect the impact of the consumption motive or that age may be a better (inverse) measure of health status than the crude self-evaluation health question for older females. The failure for the males' profiles to reach a peak is not a statistical artifact caused by the use of a quadratic function, as the use of a cubic function in age did not increase the explanatory power of the model. Rather, after retirement the consumption value of religion may increase for males. We have no firm evidence on this point, however. 
TABLE 6

Estimated Impact of Age and Age on Frequency of Church Attendance, by Sex

\begin{tabular}{|c|c|c|c|c|c|c|c|c|}
\hline \multirow[b]{2}{*}{ ReLigion } & \multirow[b]{2}{*}{$F(m, n)$} & \multicolumn{3}{|c|}{ Female } & \multicolumn{3}{|r|}{ MALE } & \multirow[b]{2}{*}{$\begin{array}{c}\text { Overtaking } \\
\text { Age }\end{array}$} \\
\hline & & Age & $\mathrm{Age}^{2}$ & $\begin{array}{c}\text { Turning } \\
\text { Age }\end{array}$ & Age & $\mathrm{Age}^{2}$ & $\begin{array}{c}\text { Turning } \\
\text { Age }\end{array}$ & \\
\hline $\begin{array}{l}\text { Protestant } \ldots \ldots \ldots \ldots \ldots \ldots \\
\text { Catholic } \ldots \ldots \ldots \ldots \ldots\end{array}$ & $\begin{array}{l}6.923(3,922) R \\
1.843(3,370) N\end{array}$ & $1.548^{*}$ & -.013 & $60 \max$ & .052 & .002 & Always increasing & 50 \\
\hline Baptist $\ldots \ldots \ldots \ldots \ldots \ldots \ldots \ldots \ldots \ldots \ldots$ & $4.381(3,294) R$ & $1.980 *$ & -.017 & $58 \max$ & .007 & .002 & Always increasing & $\dddot{52}$ \\
\hline $\begin{array}{l}\text { Lutheran } \ldots \ldots \ldots \ldots \ldots \ldots \\
\text { Methodist } \ldots \ldots \ldots \ldots \ldots \ldots\end{array}$ & $\begin{array}{l}0.728(3,106) N \\
3.620(3,180) R\end{array}$ & 1.473 & -.012 & $61 \max$ & -.623 & .003 & $39 \mathrm{~min}$ & 52 \\
\hline
\end{tabular}

Note. $-F(m, n)=F$-statistic to test the null hypothesis $\left(H_{0}\right)$ and (degrees of freedom numerator, degrees of freedom denominator); $R(N)=$ reject (not reject) $H_{0}$ at .95 level of significance; $H_{0}=$ the age-frequency-of-attendance relationship is linear and does not vary by sex; $H_{a}=$ the frequency of church attendance is a function of age and age squared, (a) age $=$ age up until which the slope of the age-church attendance profile is steeper for females than males.
$*$ Individual coefficient statistically significantly different from zero at .95 level of significance, two-tailed test. 
husband and wife and the shape of a household's life-cycle religiousparticipation profile. Virtually all of the simple correlations of variables with religiosity, previously uncovered by sociologists, are consistent with our framework.

The theory has been tested using multivariate methods on two different types of data: statewide data on church-membership rates and survey data on the annual frequency of church attendance for 1,500 U.S. adults. Neither source of data is completely adequate for an empirical test of the model. The former suffers from reporting errors and incomplete coverage; the latter contains no wage-rate data and reports the frequency of church attendance for only one spouse. However, the empirical results based upon the two samples taken together provide strong support for our model.

The model which we have proposed in this paper can be easily extended in several directions. These extensions allow one to analyze a wide range of phenomena relating to the interaction of household allocation of time and religiosity. ${ }^{39}$ For example, one extension is to generalize the expected afterlife-benefit-production function to allow the substitution of market goods for household time. These goods might be interpreted as being church dues, contributions to religious charities, or contributions in general. Many implications follow directly from this extension.

First, as real wages grow over time we should expect individuals to shift toward less time-intensive forms of religious activities. This could occur by the religious institutions themselves changing; such as the development of Reform Judaism, which is less time-intensive than other forms of Judaism. ${ }^{40}$ Alternatively, if a set of religions which have relatively similar basic beliefs exists (i.e., many of the Protestant denominations), we should expect the less time-intensive religions to grow secularly relative to the more time-intensive ones. In contrast, when the unemployment rate rises, the opportunity cost of time falls for many individuals, hence we should expect to observe the reverse pattern, with more timeintensive religions growing relative to less time-intensive ones. ${ }^{41} \mathrm{Although}$ historical church-membership data is notoriously poor in quality, these implications could be tested in principle by using aggregate historical data on church membership by denomination.

Second, this model predicts that, if an individual faces an upwardsloping age-earnings profile, he should decrease the time intensity of his

39 The formal models underlying the discussion that follows are contained in an appendix that is available from the authors. In future reseach we hope to empirically test many of the hypotheses that they generate.

40 This point has been previously suggested by Gary Becker and is cited in Linder (1970). Linder also discusses examples of similar types of "institutional change" occurring in Sweden.

${ }^{41}$ Some evidence on this point is offered in Sales (1972), although his analysis focuses on authoritarian versus nonauthoritarian denominations. Casual empiricism suggests that this dichotomy may also reflect differing time intensities. 
religious activities over the course of his life cycle. This could be accomplished either through interdenominational mobility toward less timeintensive denominations or through the substitution of market goods for household time within a given denomination. With respect to the former, survey data indicate that approximately 20 percent of U.S. adult males change their religious preferences at least once during their lifetimes. ${ }^{\mathbf{4 2}}$ If measures of the time-intensity of various denominations can be developed, survey data can be used to test the implications concerning interdenominational mobility. With respect to the latter, if we interpret market goods used in religious activities as contributions to churches (or donations in general), the model provides us with a theory of life-cycle contributions. Any attempts to test such a theory, however, would require elaborating it to consider factors such as the federal tax treatment of contributions. ${ }^{43}$

Our original model as well as the generalization discussed above assume that individuals' life-cycle wage profiles are exogenous. A second extension of the model is to make life-cycle human-capital-investment decisions, and consequently wage profiles, endogenous. Under certain assumptions, one can show that the steepness of age-earnings profiles implied by such a model will vary inversely with individuals' extent of belief in an afterlife. That is, individuals who assign higher probabilities to the existence of an afterlife will tend to have relatively flatter ageearnings profiles. ${ }^{44}$ Such a model may provide an explanation of why life-cycle occupational mobility varies across religions. ${ }^{45}$ Survey data may also permit one to test whether a relationship exists between the extent of religious belief and the shape of age-earnings profiles across individuals of the same religion. ${ }^{46}$

These generalizations of the model should make it clear that we have

42 See Warren 1970.

43 Dickinson (1970) has constructed estimates of contributions to each of the major religions in the United States for the 1929-59 period.

${ }^{44}$ Formal details of such a model are also contained in the available appendix. Each household is assumed to have a subjective probability, $\Theta$, that there is an afterlife and to maximize a utility function of the form

$$
U^{*}=U^{1}\left(C_{1}, C_{2}, \ldots C_{n}\right)+\Theta U^{2}(q),
$$

where the expected afterlife-production function (3) is now interpreted as being conditional on belief in an afterlife. Specific assumptions about the shapes of the various functions then lead to the results cited in the text. This conclusion is very sensitive to the assumptions which we have made and is not a general result. Rather, we offer it only as a tentative hypothesis to be subject to future empirical testing.

${ }^{45}$ Sociologists have investigated this relationship (see Lenski 1961, Gockel 1969, Jackson, Fox, and Crocket 1970, Warren 1970, Featherman 1971, and Schuman 1971, for examples. Recently several economists, including Hause (1972) and Taubman (1974), have also observed earnings varying, ceteris paribus, across religions.

46 Unfortunately, the NORC data used in this paper contain no information on individual's wage rates or annual labor earnings. 
only begun the process of development and testing of a unified theory of household allocation of time and religiosity. They also suggest the directions which future empirical research on the subject should take. Nevertheless, we believe that the empirical results presented in the paper provide strong initial support for our approach and suggest that religious participation should be added to the growing set of nonmarket activities which have proven amenable to being analyzed in a household-allocationof-time framework. 
TABLE A1

Frequency-of-Church-Attendance Regressions: Belief-In-Afterlife Variable Omitted (Absolute Value $t$-Statistics)

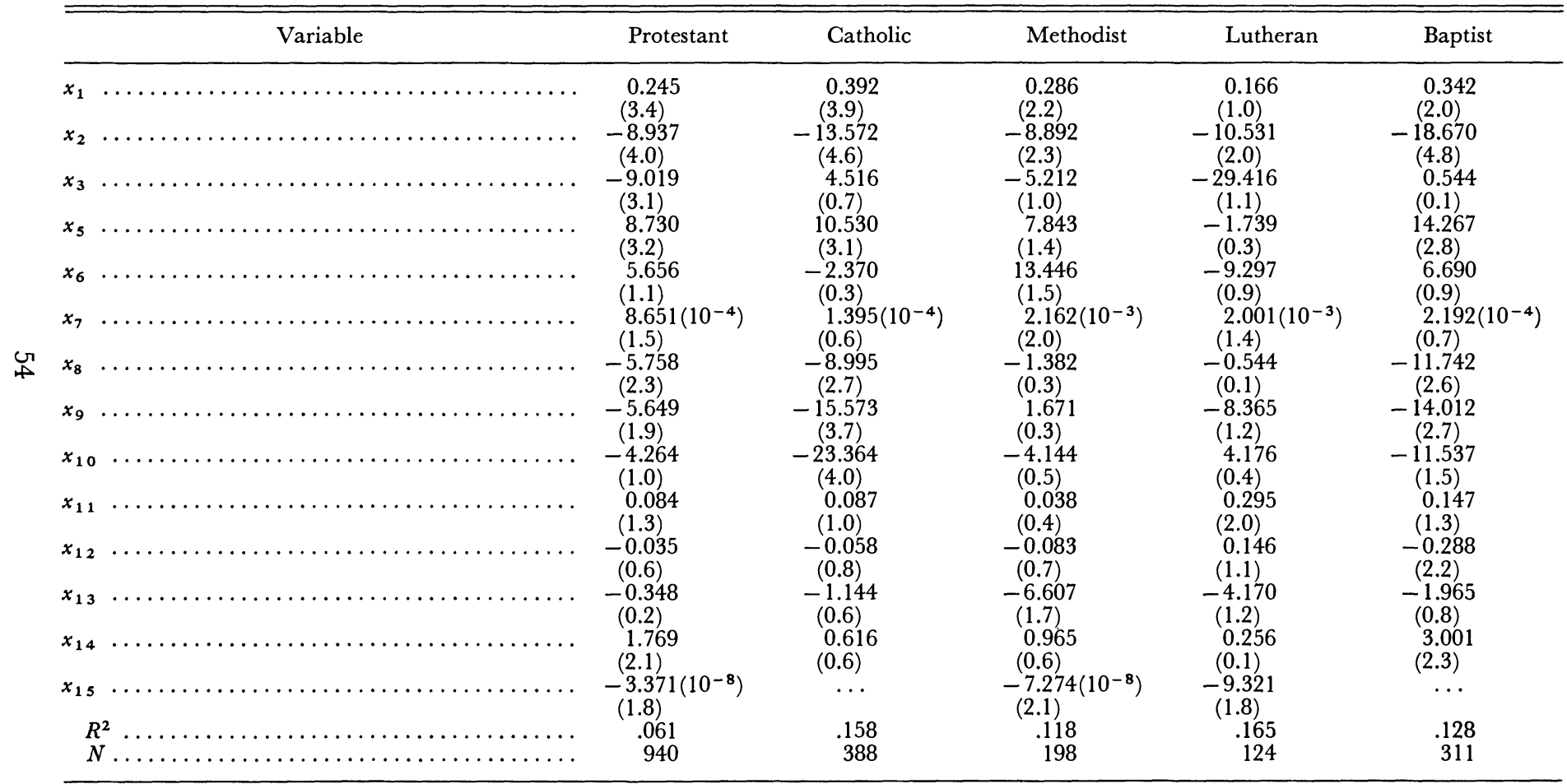

Note.-See table 5 for variable definitions. 


\section{References}

Argyle, M. Religious Behavior. Glencoe, Ill.: Free Press, 1959.

$\rightarrow$ Becker, G. "A Theory of Allocation of Time." Econ. J. 75 (September 1965): 493-517.

$\rightarrow-$ "A Theory of Marriage: Part I." J.P.E. 81, no. 4 (July/August 1973): 813-47.

Bultena, L. "Church Membership and Church Attendance in Madison, Wisconsin." American Soc. Rev. 14 (May 1948): 384-89.

Croog, S. H., and Levine S. "Religious Identity and Response to Serious Illness: A Report on Heart Patients." Soc. Sci. and Medicine 6 (February 1972) : 17-32.

Demerath, N. J. Social Class in American Protestantism. Glencoe, Ill.: Free Press, 1965.

Dickinson, F. The Changing Position of Philanthropy in the American Economy. New York: Columbia Univ. Press, 1970.

Featherman, D. "The Socioeconomic Achievement of White-Religio-Ethic Subgroups: Social and Psychological Explanations." American Soc. Rev. 36 (April 1972): 207-22.

Glock, G., and Stark, R. Religion and Society in Tension. Chicago: Rand McNally, 1965.

$\rightarrow$ Gockel, G. "Income and Religious Affiliation: A Regression Analysis." American J. Soc. 74 (May 1969): 632-47.

$\rightarrow$ Gronau, R. "The Intrafamily Allocation of Time: The Value of Housewives' Time." A.E.R. 63 (September 1973): 634-52.

$\rightarrow$ Grossman, M. "On the Concept of Health Capital and the Demand for Health." J.P.E. 80, no. 2 (March/April 1972) : 223-55.

$\rightarrow$ Hamermesh, D., and Soss, N. "An Economic Theory of Suicide." J.P.E. 82, no. 1 (January/February 1974): 83-98.

Hause, J. "Earnings Profile: Ability and Schooling." J.P.E. 80, no. 3 (suppl.; May/June 1972): 108-39.

$\rightarrow$ Jackson, E.; Fox, W.; and Crocket, H. "Religion and Occupational Achievement." American Soc. Rev. 35 (February 1970): 48-63.

Johnston, J. Econometric Methods. 2d ed. New York: McGraw-Hill, 1972.

Lazarwitz, B. "Some Factors Associated with Variations in Church Attendance." Soc. Forces 39 (May 1961): 300-309.

Leibowitz, A. "Home Investment in Children." J.P.E. 82, no. 2 (suppl.; March/ April 1974): 111-32.

$\rightarrow$ Lenski, G. "Social Correlates of Religious Interest." American Soc. Rev. 18 (October 1953): 533-44.

- The Religious Factor. Garden City, N.J.: Doubleday, 1961. 307-34.

Linder, S. The Harried Leisure Class. New York: Columbia Univ. Press, 1970.

Michael, R. "Education in Nonmarket Production." J.P.E. 81, no. 2 (March/ April, 1973): 306-28.

Miller, H. Trends in the Income of Families and Persons in the United States 1947-60. Washington: Government Printing Office, 1963.

Orbach, H. "Aging and Religion." Geriatrics 16 (1961): 530-40.

$\rightarrow$ Roof, W. C. "The Local-Cosmopolitan Orientation and Traditional Religious Commitment." Soc. Analysis 33 (Spring 1972): 1-15.

- "Explaining Traditional Religion in Contemporary Society." In Changing Perspectives in the Scientific Study of Religion, edited by A. Eister. New York: Wiley, 1973. 
Sales, S. "Economic Threat as a Determinant of Conversion Rates in Authoritarian and Nonauthoritarian Churches." J. Personality and Soc. Psychology 23 (1972): 420-48.

$\rightarrow$ Schuman, M. "The Religious Factor in Detroit: Review, Replication, and Reanalysis." American Soc. Rev. 36 (February 1971): 30-48.

Sklare, M. Conservative Judaism: An American Religious Movement. New York: Schocken, 1972.

Taubman, P. "Schooling, Ability, Nonpecuniary Rewards, Socioeconomic Background and the Lifetime Distribution of Earnings." Paper presented to the NBER conference on "Research in Income and Wealth," Ann Arbor, Mich., May 1974.

Warren, B. "Socioeconomic Achievement and Religion: The American Case." Soc. Inquiry 40 (Spring 1970): 130-55.

Willis, R. "A New Economic Approach to the Economic Theory of Fertility Behavior." J.P.E. 81, no. 2 (suppl.; March/April 1973) : 4-65. 